\title{
EFFECTS OF CORN MEAL AND SULPHURIC ACID ON THE PRODUCTION OF CACHAÇA
}

\author{
Efeitos do fubá e ácido sulfúrico sobre a produção de cachaça
}

\author{
Francisco Vicente Gaiotto Cleto ${ }^{1}$, Gisele Cristina Ravaneli², Márcia Justino Rossini Mutton ${ }^{3}$
}

\begin{abstract}
This work was carried out to evaluate the effects of using corn meal and treating yeasts with sulfuric acid on fermentation microorganisms, wine acidity, ethanol content and cachaça yield and composition. The experiment was arranged in randomized block design, in a $2 \times 3$ factorial with five replications. The methods applied in this study are recommended by distilleries. Results showed that the yeast sulfuric acid treatment transferred acidity to the fermenting juice, without any influence on yeast viability, ethanol content and cachaça yield. On the other hand, the acid treatment controlled lactic bacteria in the inoculum. Addition of corn meal increased the concentration of lactic bacteria in the end of the fermentation and increased the levels of higher alcohols in cachaça, especially propyl and isobutyl alcohol.
\end{abstract}

Index terms: yeast treatment, ethanolic fermentation, contaminating bacteria, beverage.

\section{RESUMO}

Avaliou-se o efeito da adição do fubá de milho no mosto de xarope de cana e o tratamento ácido do pé-de-cuba sobre a microbiota do processo fermentativo, acidez do vinho, grau alcoólico, rendimento e composição da cachaça. O delineamento experimental utilizado foi o de blocos casualizados, no esquema fatorial $2 \times 3$ e cinco repetições. A metodologia empregada e as análises foram as recomendadas pelo setor aguardenteiro. Os resultados permitiram concluir que a adição do ácido sulfúrico no pé-de-cuba transferiu a acidez para o vinho, não influenciando na viabilidade das leveduras, rendimento e composição da cachaça. Por outro lado, a acidificação do meio controlou as bactérias láticas no pé-de-cuba. A adição do fubá aumentou a concentração de bactérias lácticas ao final do processo fermentativo e dos álcoois homólogos superiores na cachaça, particularmente, os álcoois propílico e isobutílico.

Termos para indexação: Tratamento do fermento, fermentação alcoólica, contaminantes, bebida.

(Recebido em 21 de dezembro de 2006 e aprovado em 21 de junho de 2008)

\section{INTRODUCTION}

Cachaça is the typical and exclusive sugarcane liquor produced in Brazil, with ethanolic content of 38 to $48 \%$ in volume, at $20^{\circ} \mathrm{C}$. It is obtained from the distillation of fermented sugarcane must, with particular sensorial characteristics (BRASIL, 2002). In the production of this beverage, besides yeasts that produce ethanol and secondary components, there are contaminating bacteria from the cane raw material and from the water used in the process, which may influence the final product. The predominant species in the fermentation process are Lactobacillus and Leuconostoc (ROSALES, 1989; GALLO, 1992), which require more attention since they adapt better to the predominant conditions of yeast fermentation media.

According to Chaves \& Póvoa (1992), the mean acidity of the sugarcane juice corresponds to a $\mathrm{pH}$ value around 5.50. Although the optimal $\mathrm{pH}$ value for the fermentation yeasts are close to 4.50 , one observed that the juice acidity is practically enough for the appropriate fermentation. However, situations may happen, in which the reduction of the $\mathrm{pH}$ value of the fermentation must is necessary. For that, it is suggested the addition of some acid, like the sulfuric one, in appropriate amounts.

According to Maia et al. (1993), corn meal is rich in amino acids like leucine, valine and treonine and has an important function in the adsorption by the starch of secondary metabolites from the ethanolic fermentation, whose presence in the must affects the kinetics of the glycolytic pathway.

Regarding the importance of the fermentation additives, microbes in the fermentation process and their influence in the parameters related to cachaça, this study

\footnotetext{
'Engenheiro Agrônomo, Doutor em Microbiologia Agropecuária - Serviço de Fiscalização Agropecuária/SEPAG - Ministério da Agricultura, Pecuária e Abastecimento/MAPA - Rodovia Anhanguera, Km 312 - Jardim Aeroporto - Cx. P. 170 - 14001-970 - Ribeirão Preto, SP - fvgaiotto@ig.com.br Engenheiro Agrônomo, Mestre em Microbiologia Agropecuária - Departamento de Tecnologia - Faculdade de Ciências Agrárias e Veterinárias/FCAV Universidade Estadual Paulista/UNESP - Via de Acesso Professor Paulo Donatto Castellane, s/n - Zona Rural - 14884-900 - Jaboticabal, SP giravaneli@gmail.com

${ }^{3}$ Engenheira Agrônoma, Doutora em Solos e Nutrição de Plantas, Professora Adujunto - Departamento de Tecnologia - Faculdade de Ciências Agrárias e Veterinárias/FCAV - Universidade Estadual Paulista/UNESP - Via de Acesso Professor Paulo Donatto Castellane, s/n - Zona Rural - 14884900 - Jaboticabal, SP - mjrmut@fcav.unesp.br
} 
was developed in order to evaluate the action of the sulfuric acid and corn meal on yeasts and bacteria in the fermentation process, as well as the composition of cachaça.

\section{MATERIAL AND METHODS}

Must was obtained from cane syrup, produced in Jaboticabal-SP, and showed the following characteristics: $15.1{ }^{\circ}$ Brix, $12.2 \%$ of Pol - as determined according to Scheneider (1979); $0.74 \%$ of Reducing Sugars (RS) and $14.5 \%$ of Total Reducing Sugars (TRS) (determined as described by Lane \& Eynon (1934); $0.62 \mathrm{~g} \mathrm{H}_{2} \mathrm{SO}_{4} / \mathrm{L}$ of Total Acidity (COPERSUCAR, 2001) and $\mathrm{pH}=6.0$.

\section{Fermentation and distillation procedures}

Yeasts used in the fermentation process were obtained from the pressed baker yeast, which consists of an agglomerate of Saccharomyces cerevisiae cells.

The yeast inoculum consisted of $300 \mathrm{~g}$ of ferment in $600 \mathrm{ml}$ of water. The acid treatment was accomplished through the addition of concentrated sulfuric acid, enough to reach 2.5-3.0 and 3.0-3.5 pH values. To the 5.07.0 range of $\mathrm{pH}$ values there was not acid addition. After two hours, the must was partially added to the vats, starting the fermentation process. The total volume of the vats was $3000 \mathrm{~mL}(2100 \mathrm{~mL}$ of must and $900 \mathrm{~mL}$ of yeast suspension). $15.0 \mathrm{~g} / \mathrm{L}$ of corn meal were added to the must.

The stainless steel vats were put in water-bath, coupled to an ultra-cryostat MK-70 (MLW) to keep the temperature $\left(30^{\circ} \mathrm{C}\right)$ during the whole process. At the end of fermentation after 14 hours, the wines were submitted to $\mathrm{pH}$, Sulfuric Acidity (COPERSUCAR, 2001) and Total Residual Reducing Sugars (TRRS) analyses, according to Copersucar (1988).

The distillation was performed in glass distiller with a copper device, somprised by a 3-L distillation flask, reflux condenser, wine admission and thermometer, and conducted as described by Cleto \& Mutton (1997). From each treatment, $200 \mathrm{~mL}$ of chaçaca were obtained. Distillation products wew submitted to gas chromatography for compound analyses. Results are shown in Table 3.

\section{Microbiological Analysis}

The lactic acid bacteria were isolated at the beginning and at the end of the fermentation, and appraised by plating and using MRS-agar culture medium.
The viability rating of fermentation yeasts was determined through cells counting in a Neubauer's chamber (LEE et al., 1981).

\section{Statistical design}

The experiment was arranged in randomized blocks, according to Banzatto \& Kronka (2006), in a 2x3 factorial with 5 blocks, and two factors were used: corn meal in two levels - absence and presence - and three levels for acid (pH 2.5-3.0; 3.0-3.5 and 5.0-7.0); Means were compared by Tukey Test at $5 \%$ of probability.

\section{RESULTS AND DISCUSSION}

\section{pH and sulfuric acidity during fermentation process}

The obtained values showed that sulfuric acid addition in the starting yeast was inversely proportional to the variation of the $\mathrm{pH}$, in other words, the highest level of sulphuric acid led to smallest $\mathrm{pH}$ and larger acidity of the wines (Table 1). Such results were foreseen and corroborate with Cleto \& Mutton $(1996,1997)$.

Different results are observed considering highly infected musts. The acid addition to the yeast may control the bacteria multiplication in the fermentation process, minimizing the acids production by the contaminating microorganisms, thus obtaining a wine with higher $\mathrm{pH}$ value and smaller acidity. However, in this study, the syrup showed small amounts of contaminating microorganisms.

As for the corn meal used in the must, no alteration in the $\mathrm{pH}$ values and wine acidity were observed. The results obtained by Cleto \& Mutton $(1996 ; 1997)$ are in agreement with this observation

\section{Contaminating Microorganisms of Alcoholic Fermentation}

On Table 2, it may be verified that the counts for microorganisms in the yeast inoculum were significantly smaller, as to the total microorganisms as to the lactic bacteria, in the treatments where acid was added, in the $\mathrm{pH}$ ranges of 2.5-3.0 and 3.0-3.5. Firstly, one verified that the used ferment contained a great amount of bacteria, in the order of $10^{8} \mathrm{UFC} / \mathrm{mL}$ (data not shown), and that the acid added to the yeast controlled the multiplication of those bacteria. These results are confirmed by Chaves \& Póvoa (1992) and Gallo \& Canhos (1991), who concluded that the sulfuric acid addition in the process significantly reduces the amount of contaminating bacteria. 
Table 1 - Means for the technological analyses of yeasts, wine and cachaça. Jaboticabal/SP.

\begin{tabular}{ccccccccc}
\hline & \multicolumn{2}{c}{$\mathrm{pH}$} & \multicolumn{2}{c}{ Acidity } & TRRS & $\begin{array}{c}\text { Ethanol } \\
\text { Content }\end{array}$ & $\begin{array}{c}\text { Cachaça } \\
\text { Yield }\end{array}$ \\
\hline & Yeasts & Wine & \multicolumn{2}{c}{ Yeasts } & Wine & & & \\
\hline & & & \multicolumn{2}{c}{$\mathrm{g} \mathrm{H}_{2} \mathrm{SO}_{4 /} \mathrm{L}$} & $\%$ & $\% \mathrm{v} / \mathrm{v}$ & $\%$ \\
\hline with corn meal & -- & $4.2 \mathrm{~A}$ & -- & $1.8 \mathrm{~A}$ & $0.06 \mathrm{~A}$ & $38.7 \mathrm{~A}$ & $59.2 \mathrm{~A}$ \\
\hline withouth corn meal & -- & $4.2 \mathrm{~A}$ & -- & $1.8 \mathrm{~A}$ & $0.07 \mathrm{~A}$ & $38.8 \mathrm{~A}$ & $56.9 \mathrm{~A}$ \\
\hline $\mathrm{pH} 2.5-3.0$ & $2.5 \mathrm{C}$ & $4.0 \mathrm{~B}$ & $1.5 \mathrm{~A}$ & $1.9 \mathrm{~A}$ & $0.06 \mathrm{~A}$ & $38.7 \mathrm{~A}$ & $59.2 \mathrm{~A}$ \\
\hline $\mathrm{pH} 3.0-5.0$ & $3.2 \mathrm{~B}$ & $4.1 \mathrm{~B}$ & $1.2 \mathrm{~B}$ & $1.9 \mathrm{~A}$ & $0.06 \mathrm{~A}$ & $39.1 \mathrm{~A}$ & $59.6 \mathrm{~A}$ \\
\hline $\mathrm{pH} \mathrm{5.0-7.0}$ & $5.9 \mathrm{~A}$ & $4.3 \mathrm{~A}$ & $0.9 \mathrm{C}$ & $1.7 \mathrm{~B}$ & $0.07 \mathrm{~A}$ & $38.4 \mathrm{~A}$ & $59.2 \mathrm{~A}$ \\
\hline
\end{tabular}

Means followed with the same letter do not differ by Tukey Test $(\mathrm{P}<0.05)$.

Table 2 - Means for the microbiological characteristics of the yeast and wine. Jaboticabal/SP.

\begin{tabular}{lcccccr}
\hline & \multicolumn{2}{c}{ Bact. count } & \multicolumn{2}{c}{ Lactic bacteria (MRS media) } & \multicolumn{2}{c}{ Viability level } \\
\hline & Yeast & wine & Yeast & Wine & Yeast & Wine \\
\hline & & & & & & \\
\hline Corn meal & -- & $42.3 \mathrm{~A}$ & -- & $75.9 \mathrm{~A}$ & -- & $78.9 \mathrm{~A}$ \\
\hline Control & -- & $35.9 \mathrm{~A}$ & -- & $26.4 \mathrm{~A}$ & -- & $76.8 \mathrm{~A}$ \\
\hline $\mathrm{pH} 2.5-3.0$ & $25.1 \mathrm{~B}$ & $41.2 \mathrm{~A}$ & $98.2 \mathrm{~B}$ & $11.6 \mathrm{~B}$ & $98.7 \mathrm{~A}$ & $76.8 \mathrm{~A}$ \\
\hline $\mathrm{pH} 3.0-5.0$ & $28.2 \mathrm{~B}$ & $37.5 \mathrm{~A}$ & $96.9 \mathrm{~B}$ & $49.3 \mathrm{AB}$ & $98.9 \mathrm{~A}$ & $78.6 \mathrm{~A}$ \\
\hline $\mathrm{pH} 5.0-7.0$ & $38.5 \mathrm{~A}$ & $38.7 \mathrm{~A}$ & $207.4 \mathrm{~A}$ & $92.7 \mathrm{~A}$ & $99.4 \mathrm{~A}$ & $78.2 \mathrm{~A}$ \\
\hline
\end{tabular}

Bact. Count $=$ Microscopic bacteria counting

Lact. Bact. = Lactic bactéria counting $\left(\right.$ microorganisms $/ \mathrm{mL} \mathrm{x} \mathrm{10^{7 } )}$

Viability level $=$ Yeast viability $(\%)$

Means followed by the same letter do not differ by Tukey Test $(\mathrm{P}<0.05)$.

According to Gallo (1992) and Rosales (1989), the highest amount of bacteria found in the fermentation process belongs to the Lactobacillus species. According to these authors, the treatment of the yeast with sulfuric acid, significantly reduces the amount of these microorganisms. These observations are in agreement with this study (Table 1), in which the acid treatment ( $\mathrm{pH}$ ranges of 2.5-3.0 and 3.0-3.5) reduced the number of lactic bacteria. One also verified that, in spite of the acid treatment of the yeast $(\mathrm{pH}$ 2.5-3.0 and 3.0-3.5) significantly reduce the amount of total bacteria during the fermentation process, it happened a recovery in the population of those bacteria during the process, and that in the end of the fermentation there was no significant difference among those microorganisms.

For the corn meal (Table 2), the means were significant for the counting of lactic bacteria, indicating that this product interferes in the metabolism of the bacteria present in the fermentation process, increasing their population.

\section{Yeasts cell viability during fermentation process}

There was no significant difference $(\mathrm{P}>0.05)$ when the means of the cellular viability of the yeasts were analyzed (Table 2). The results did not corroborate Chaves \& Povoa (1992) observations, which indicated that the acid addition in the fermentation process benefits the yeasts. Bovi \& Marques (1983) emphasize that the cellular viability can be affected when the $\mathrm{pH}$ values of the yeasts are close or below 2.0. However, it can be verified that the behavior of the fermentation process is not affected when there is no acid addition. These results are similar to the ones of Blanchet \& Ballerini (1987) and Chaves \& Póvoa (1992).

Also, the cellular viability didn't differ significantly $(\mathrm{P}>0.05)$ in treatments with and without corn meal addition, confirming the results obtained by Maia et al. (1993) and 
Maia \& Nelson (1994), who observed that the corn meal addition in the fermentation process did not interfere in the cellular viability of the yeasts.

\section{Total Residual Reducing Sugars (TRRS), Ethanol Content} and Yield of Cachaça

Total Residual Reducing Sugars (TRRS) did not differ significantly $(\mathrm{P}>0.05)$ when the means of the factors were compared (Table 1). This behavior indicates that practically all of the fermentable sugars were consumed by the microorganisms, resulting in complete fermentations. The analyzed factors (acid and corn meal) did not disturb the fermentation.

No significant difference $(\mathrm{P}>0.05)$ was found for ethanolic content and cachaça yield (Table 1). One verified that when the must is used with small amounts of contaminating bacteria, as in the case of the syrup must, there is no need to use the additives studied in the fermentation process.

\section{Secondary Components of Cachaça}

There was no significant difference $(\mathrm{P}>0.05)$ when the acetic acid, acetaldehyde and ethyl acetate compounds were analyzed for the considered factors (Table 03), although the acidity of the wines was between 1.7 and 1.9 $\mathrm{g} / \mathrm{L}$ of $\mathrm{H}_{2} \mathrm{SO}_{4}$, which are considered as low values to influence the increase of these compounds in cachaça.

Regarding the corn meal addition to the must, it was observed that there was no alteration in the concentration of these three studied compounds. According to Maia (1994), the harmful effect of these compounds is practically eliminated by the corn meal addition or soy flour to the must. The corn meal may reduce the amount of acids in the wine, due to action of the starch on the short chain fatty acids, acting as adsorbent (MAIA \& NELSON, 1992), when great amounts of acid producing bacteria exist in the fermentation process. In this experiment, the amount of contaminating microorganisms was low (Table 02), having no significant adsorption of the corn meal regarding the short chain fatty acids.

There were significant differences when the means of the higher alcohols (HA) of the distilled were analyzed (Table 03). The concentration of these alcohols was larger when they came from wines in which corn meal was added. Similar results were obtained by Cleto \& Mutton (1997).

The corn meal is rich in amino acids such as leucine, valine and threonine. These amino acids are usually metabolized by the yeasts, forming the propyl, isobutyl and isoamyl alcohols as by-products. According to Engan (1970), the concentrations of the isoamyl and isobutyl alcohols are increased by the addition of leucine and valine, respectively, in the fermentation medium. For Reazin et al. (1973), the alcohols n-propyl, d-amyl and isoamyl, are also formed from the threonine. It is also pointed out that the yeasts produce HA from sugars (CROWELL et al., 1961; INGRAHAM \& GUIMON, 1960), independent of the addition of those amino acids in the medium. However, when they are added in the fermentation medium, pure or intrinsic to the fermentation additives like corn meal, the increase of HA may be verified.

It has been evidenced the increase of the concentrations of the isobutyl and propyl alcohols, while there was no differences for isoamyl alcohol. Probably the corn meal used in the experiment, contained larger amounts of threonine and valine and little leucine.

From the analysis of the yield, alcoholic content and composition of the cachaça, one observed that the control of the lactic bacteria by the yeast treatment with acid, and the corn meal addition in the fermentation process, did not implicate in the improvement of these parameters, because the used raw material was in good sanitary conditions. The farmers that operate under the

Table 3 - Values obtained for cachaça secondary components. Jaboticabal/SP.

\begin{tabular}{cccccccc}
\hline & Acetaldehyde & Acetic acid & $\begin{array}{c}\text { Ethyl } \\
\text { acetate }\end{array}$ & $\begin{array}{c}\text { Propyl } \\
\text { alcohol }\end{array}$ & $\begin{array}{c}\text { Isobutyl } \\
\text { alcohol }\end{array}$ & $\begin{array}{c}\text { Isoamilic } \\
\text { alcohol }\end{array}$ & HA \\
\hline Corn meal & $33.7 \mathrm{~A}$ & $27.5 \mathrm{~A}$ & $49.8 \mathrm{~A}$ & $52.5 \mathrm{~A}$ & $189.0 \mathrm{~A}$ & $457.9 \mathrm{~A}$ & $699.3 \mathrm{~A}$ \\
Control & $34.2 \mathrm{~A}$ & $30.6 \mathrm{~A}$ & $52.0 \mathrm{~A}$ & $39.3 \mathrm{~B}$ & $148.9 \mathrm{~B}$ & $478.0 \mathrm{~A}$ & $670.5 \mathrm{~A}$ \\
\hline pH 2.5-3.0 & $34.5 \mathrm{~A}$ & $28.0 \mathrm{~A}$ & $49.9 \mathrm{~A}$ & $42.6 \mathrm{~A}$ & $170.0 \mathrm{~A}$ & $470.8 \mathrm{~A}$ & $683.5 \mathrm{~A}$ \\
$\mathrm{pH} 3.0-5.0$ & $33.5 \mathrm{~A}$ & $30.2 \mathrm{~A}$ & $52.9 \mathrm{~A}$ & $46.6 \mathrm{~A}$ & $172.3 \mathrm{~A}$ & $472.3 \mathrm{~A}$ & $691.3 \mathrm{~A}$ \\
$\mathrm{pH} 5.0-7.0$ & $33.9 \mathrm{~A}$ & $28.9 \mathrm{~A}$ & $49.8 \mathrm{~A}$ & $48.5 \mathrm{~A}$ & $164.5 \mathrm{~A}$ & $460.7 \mathrm{~A}$ & $680.1 \mathrm{~A}$ \\
\hline
\end{tabular}

$\mathrm{HA}=$ Higher alcohols

Means followed by the same letters do not differ by Tukey's Test $(\mathrm{P}<0.05)$. 
rules of good production practices, that is, who manage to harvest the sugarcane ripe, without straw, immediately crushed after the crop, and maintain good asepsis of the fermentation process, do not need to use these additives (acid and corn meal) in the ethanolic fermentation. Those cares with the raw material and development of the process, implicate in a lower production cost of cachaça and larger easiness in the fermentation development, as well as a better quality final product.

\section{CONCLUSIONS}

The yeast acid treatment and the corn meal addition to the must, as additives in ethanolic fermentation do not influence the ethanolic content and cachaça yield;

The corn meal and acid addition to the fermentation process leads to the increase and decrease, respectively, of the lactic bacteria population;

The distilleries that work under the adequate production practieces do not need to use corn meal and acid additives.

\section{REFERENCES}

BANZATTO, D. A.; KRONKA, S. N. Experimentação agrícola. 2. ed. Jaboticabal: FUNEP, 1995. 247 p.

BLANCHET, D.; BALLERINI, D. La fermentation éthanolique. paramètres controlant le métabolism et la fermentation che les levures. Revue de L'institut Français du Pétrole, Paris, v. 42, n. 3, 1987.

BOVI, R.; MARQUES, M. O. O tratamento ácido na fermentação alcoólica. Álcool \& Açúcar, São Paulo, v. 3 , n. 9, p. 10-13, 1983.

BRASIL. Decreto n. 4072, de 3 de janeiro de 2002. Dispõe sobre a padronização, a classificação, o registro, a inspeção, a produção e a fiscalização de bebidas. Brasília, DF, cap. IV, seção IV, art. 92, 2002.

CHAVES, J. B. P.; PÓVOA, M. E. B. A qualidade da aguardente de cana de açúcar. In: MUTTON, M. J. R.; MUTTON, M. A. Aguardente de cana: produção e qualidade. Jaboticabal: FUNEP, 1992. p. 93-132.

CLETO, F. V. G.; MUTTON, M. J. R. Influência de dois tipos de leveduras, do tratamento ácido e da adição de fubá de milho sobre o desenvolvimento do processo fermentativo e qualidade final do destilado. Stab: Açúcar, Álcool e Subprodutos, Piracicaba, v. 14, n. 3, p. 28-30, 1996.
CLETO, F. V. G.; MUTTON, M. J. R. Rendimento e qualidade da aguardente de cana produzida utilizando fermento tratado com ácido sulfúrico e fubá de milho. Stab: Açúcar, Álcool e Subprodutos, Piracicaba, v. 16, n. 2, p. 38-40, 1997.

\section{COPERSUCAR. Manual de controle químico da fermentação. São Paulo, 1988. 46 p.}

\section{COPERSUCAR. Manual de controle químico da fabricação de açúcar. Piracicaba, 2001.}

CROWELL, E. A. et al. Techniques for studying the mechanism of higher alcohol formation by yeast. American Journal Enology and Viticulture, v. 12, p. 111-116, 1961.

ENGAN, S. The influence of some amino acids on the formation of higher aliphatic alcohol and esters. Journal of the Institute of Brewing, v. 76, p. 254-256, 1970.

GALLO, C. R. Identificação de bactérias contaminantes da fermentação alcoólica. Stab: Açúcar, Álcool e Subprodutos, Piracicaba, v. 10, n. 5, p. 30-34, 1992.

GALLO, C. R.; CANHOS, V. P. Efeito do tratamento ácido no fermento sobre a microbiota bacteriana contaminante da fermentação alcoólica. Stab: Açúcar, Álcool e Subprodutos, Piracicaba, v. 9, n. 6, p. 35-37, 1991.

INGRAHAM, J. L.; GUYMON, J. F. The formation of higher aliphatic alcohols by mutant strains of Saccharomyces cerevisiae. Archives of Biochemistry Biophysics, v. 88, p. 157-156, 1960.

\section{LANE, J. H.; EYNON, L. Detemination of reducing sugars by fehling solution with methylene blue indicator. London: N. Rodger, 1934. 8 p.}

LEE, S. S.; ROBINSON, F. M.; WONG, H. Y. Rapid determination of yeast viability. Biotechnology Bioengineering Symposium, v. 11, 1981.

MAIA, A. B. R. A. Componentes secundários da aguardente. Stab: Açúcar, Álcool e Subprodutos, Piracicaba, v. 12, n. 6, p. 29-34, 1994.

MAIA, A. B. R. A. et al. Ação do fubá e da farinha de soja sobre a evolução da fermentação alcoólica em Saccharomyces cerevisiae. Stab: Açúcar, Álcool e Subprodutos, v. 11, n. 5, p. 22-27, 1993. 
MAIA, A. B. R. A.; NELSON, D. Comparative study of soy and corn flours on the of alcoholic fermentation in sucessive batches. Journal of Chemical

Technology andBiotechnology, London, v. 59, p. 171179, 1994.

REAZIN, G. et al. Production of higher alcohols from threonine and isoleucine in alcoholic fermentations of differents types of grain mash. Journal of Agricultural and Food Chemistry, v. 21, n. 1, p. 50-54, 1973.
ROSALES, S. Y. R. Contaminantes bacterianos da fermentação etanólica: isolamentos em meios diferenciais, identificação e avaliação de desinfetantes. 1989. 200 f. Tese (Doutorado em Ciências Biológicas) - Universidade Estadual Paulista, Jaboticabal, 1989.

SCHENEIDER, F. (Ed.). Sugar analysis methods. Peterborough: ICUMSA, 1979. 256 p. 